\title{
Nanoparticles as Potential Antivirals in Agriculture
}

\author{
Marcela Vargas-Hernandez ${ }^{1}$, Israel Macias-Bobadilla ${ }^{2}$, Ramon Gerardo Guevara-Gonzalez ${ }^{2}$, \\ Enrique Rico-Garcia ${ }^{2}$, Rosalia Virginia Ocampo-Velazquez ${ }^{2}$, Luciano Avila-Juarez ${ }^{1}{ }^{(0)}$ and \\ Irineo Torres-Pacheco ${ }^{2, *}$ \\ 1 Faculty of Engineering, Campus Amealco, Autonomous University of Queretaro, Carretera Amealco \\ Temazcaltzingo, km 1, Centro, C.P., Amealco de Bonfil, Queretaro 76850, Mexico; \\ marcela.vhz@gmail.com (M.V.-H.); lucianoavila.j@hotmail.com (L.A.-J.) \\ 2 Laboratory of Biosystems Engineering, Faculty of Engineering, Campus Amazcala, Autonomous University \\ of Queretaro, Carretera a Chichimequillas, km 1 S/N, C.P., El Marques, Queretaro 76265, Mexico; \\ ie.ti.israel@gmail.com (I.M.-B.); ramonggg66@gmail.com (R.G.G.-G.); \\ ricog@uaq.mx (E.R.-G.); rosov05@yahoo.com.mx (R.V.O.-V.) \\ * Correspondence: irineo.torres@uaq.mx; Tel.: +52-44-2192-1200
}

Received: 28 August 2020; Accepted: 20 September 2020; Published: 30 September 2020

\begin{abstract}
Viruses are estimated to be responsible for approximately $50 \%$ of the emerging plant diseases, which are difficult to control, and in some cases, there is no cure. It is essential to develop therapy practices to strengthen the management of these diseases caused by viruses in economically important crops. Metal nanoparticles (MeNPs) possess diverse physicochemical properties that allow for them to have a wide range of applications in industry, including nanomedicine and nano-agriculture. Currently, there are reports of favorable effects of the use of nanoparticles, such as antibacterial, antifungal, and antiviral effects, in animals and plants. The potential antiviral property of MeNPs makes them a powerful option for controlling these histological agents. It is crucial to determine the dosage of NPs, the application intervals, their effect as a biostimulant, and the clarification of the mechanisms of action, which are not fully understood. Therefore, this review focuses on discussing the ability of metal nanoparticles and metal oxides to control viruses that affect agriculture through an exhaustive analysis of the characteristics of the particles and their interaction processes for a possibly beneficial effect on plants.
\end{abstract}

Keywords: plant virus; diseases; nanotechnology; biostimulant

\section{Introduction}

Nanoparticles (NPs) are generally defined as particulate matter with sizes ranging from 1 to $100 \mathrm{~nm}$ [1]. This broad class of materials can be classified into metallic and non-metallic nanoparticles; the latter consists of ceramic nanoparticles (e.g., hydroxyapatite, silica, alumina), polymeric nanoparticles, and solid lipid nanoparticles [2]. The importance of nanoscale compounds is derived from the inherent properties they possess (optically active, reactivity toughness, surface area, mechanically strong, and chemically reactive). NPs offer improved features depending on their size, shape, and structure, some of which are not present in bulk materials [1]. Although nanoparticles allow for a wide range of applications in areas including catalysis, photonics, molecular computing, energy storage, fuel cells, and tunable resonant devices [3], NPs have received much attention from some scientists and researchers in different areas of the biological sciences [4]. Nanobiotechnology is biotechnology at the nanoscale and covers many applications in other fields, from agriculture to medicine [5]. Nanoscale particles have been explored in various biological applications such as biosensors, biological separation, molecular imaging, cancer therapy [6]. 
Nanomedicine, for its part, allows for the diagnosis, treatment, and prevention of diseases [7] due to NPs' antimicrobial, antiviral [8,9], and anticancer [10] properties, among others. The successful use of nanoparticles in the area of in vitro nanomedicine has generated considerable interest in their application in the field of agro-nanotechnology [11]. The advantages of its use in crop production are a reduction in the use of chemicals, water, and nutrient management; improving the assimilation during fertilization; increased yield through pest and nutrient management [12].

Plant viruses have a severe negative impact on agriculture and it is essential to make considerable efforts to control viral diseases [13]. According to one estimate, viruses are responsible for approximately $50 \%$ of the emerging plant diseases, and agriculture has a vital role in their dispersion [14]. Almost 900 species of plant viruses that infect more than 700 crop species have been reported $[9,15]$. The magnitude of the impact of viruses on plants varies depending on the stage of infection, environment, strain of the virus, type of host, speed of replication, and virus concentration [16]. Under favorable circumstances for the pathogen, the symptoms that viral infections can cause are mottling, drying of leaves, malformation of fruit, necrosis, plant stunting, and even death [9]. The main problem in the control of diseases is that they are challenging to cure, and in the case of viruses, there is no cure; the only options are to prevent or avoid infection [17,18]. Currently, nanoscale materials have emerged as novel antibacterial, antifungal, and antiviral compounds for use in animals and, to a lesser extent, in plants $[9,19,20]$. The development of antiviral agents is a promising area and the use of metal nanoparticles can be a new opportunity for novel antiviral therapies in crops. As such, in this study, we analyzed the potential of metal nanoparticles as a therapy against pathogenic viruses that damage plants, creating areas of opportunity for the use of metal nanoparticles for the management of viral diseases in agriculture.

\section{Current Options for Controlling Virus Diseases in Agriculture}

The worldwide loss of cultivation caused by viruses reaches around $20 \%$. However, some infections can generate $100 \%$ crop losses, mainly in developing countries, reaching a cost of USD 60 billion annually [9]. The problems caused by the virus have been the aggravation of crops due to changes in cultural practices and climate [21]. Virus infections have become significant and demand effective management practices to control them. Some strategies carried out in greenhouses are the reduction of insect vector populations through the use of chemical compounds or biological control [22]. Mainly because viruses depend on insect vectors for their survival, transmission, and propagation [23]. Other practices include the reduction of virus sources (infected plants or plant remains) interference with a vector's landing by altering the attraction of insects to colors, and interference with the transmission process through the use of mineral oils [22].

Other techniques that have been carried out in the laboratory for the management of viral diseases in crops include conventional and advanced practices [15]. Within conventional strategies, we find meristem tip culture, cryotherapy, thermotherapy, and chemotherapy. However, these techniques have many limitations since they are only used in tissue cultures and consider the reduction of the initial inoculum. In comparison, the advanced methods consist of RNA silencing, cross-protection, transgenic plants, gene pyramiding, and protein-protein interaction [15]. In the latter, the virus can be eliminated in plant tissues (as opposed to simply avoiding or delaying the infection), though this process does interfere with the vectors, use of attenuated strains and resistant or tolerant varieties, and is very expensive [24-26]. Chemotherapy consists of the use of antivirals that treat some diseases in animals and is also useful for the treatment of viruses in plant tissue cultures [27]. Antivirals used in plant tissue culture conditions are acycloguanosine (Acyclovir), 5-azacytidine, cytarabine, 5-bromouracil, ribavirin (Virazole), 2-thiouracil azidothymidine (Zidovudine), and 2, 4-dioxohexahydro-2, 5-triazine (DHT). Some treated diseases are potato leafroll virus (PLRV) [28], grapevine vitivirus [29], sugarcane mosaic virus (SCMV) [30], and Indian citrus ringspot virus (ICRSV) [27]. The disadvantages of chemical antivirals are that they all have different modes of action, they are not effective ex vitro, and none are selective enough to be useful against viral crop diseases [15]. 
Meanwhile, advanced methods, such as the RNA interference (RNAi)-mediated response, consist of silencing through dsRNA. The excess RNA is modified to dsRNA using RdRP (RNA-dependent RNA polymerase), allowing for RNA silencing; this technique is also used to control vector insects. However, studies are necessary for the evaluation of resistance efficiency in the crop field [15]. The control of viral diseases in plants also includes the use of resistant varieties or a cross-protection technique, which consists of a systematic infection with a second virus to induce resistance to the target virus. One of the major approaches undertaken to reduce crop losses is the use of resistant varieties since they are the most economical and most useful; however, the development of highly effective and durable virus-resistant/immune crop varieties is required [31]. Furthermore, gene pyramiding involves the stacking of multiple genes, resulting in the simultaneous expression of various genes in a variety; however, its disadvantages are its epistatic effect and high costs [15].

\section{Metallic Nanoparticles}

Metallic nanoparticles (MeNPs) comprise pure metals and metal oxides, where the latter are produced by the addition of oxidizing agents (e.g., $\mathrm{H}_{2} \mathrm{SO}_{4}, \mathrm{KMnO}_{4}$, or $\mathrm{K}_{2} \mathrm{Cr}_{2} \mathrm{O}_{7}$ ) [32]. Some examples of the most common MeNPs include gold $(\mathrm{Au})$, nickel $(\mathrm{Ni})$, silver $(\mathrm{Ag})$, platinum $(\mathrm{Pt})$, and iron (II, III). On the other hand, the metal oxide nanoparticles (MoNPs) include several compounds, such as $\mathrm{Al}_{2} \mathrm{O}_{3}, \mathrm{CeO}_{2}, \mathrm{CuO}, \mathrm{Cu}_{2} \mathrm{O}, \mathrm{In}_{2} \mathrm{O}_{3}, \mathrm{La}_{2} \mathrm{O}_{3}, \mathrm{MgO}, \mathrm{NiO}, \mathrm{TiO}_{2}, \mathrm{SnO}_{2}, \mathrm{ZnO}$, and $\mathrm{ZrO}_{2}$ [33]. The morphological characteristics of the nanoparticles depend on the conditions of the processes used to make them. The production of nanoparticles is done using two basic strategies: top-down, which consists of breaking the material, while the bottom-up strategy creates nanomaterials from atoms or molecules [34]. The top-down strategy includes mechanicosynthetic, compaction and consolidation, thermal, high-energy, plasma, chemical fabrication, and lithographic methods. On the other hand, bottom-up approaches include chemical vapor deposition, atomic layer deposition, molecular beam epitaxy, and liquid-phase methods. Chemical, physical, or biological methods can produce nanoparticles. The advantage of physical processes is that it is possible to obtain more significant quantities of nanoparticles. In contrast, the colloidal chemical synthetic process can control the size and shape of the nanoparticle [35]. There are also green nanoparticle synthesis methods that are used to reduce the damage caused by various chemical compounds [36]. The objective of green synthesis is partly to decrease the use of dangerous reagents and products and to save energy [37]. Compounds present in the plant extracts that are used to carry out the production of nanoparticles are ketones, aldehydes, flavones, amides, terpenoids, carboxylic acids, phenols, and ascorbic acid [38]. However, the problems faced by the different synthesis methods for these types of compounds are the functionality of the NPs and control of the crystal growth, stability, and mobility, as well as controlling the agglomeration, size, and shape [39]. It is essential to control several additional physicochemical variables $(\mathrm{pH}$, ionic strength, the concentration of NPs, and natural organic matter) to avoid these problems [40].

Because the synthesis methods largely determine the geometry of the nanoparticles, these affect the physicochemical properties of NPs, such as the size, dispersity, type of extrinsic and/or intrinsic defects, morphology, and crystal structure [3]. The size of the NPs influences their entry into cells and interactions with biomolecules [41]. On the other hand, the cellular uptake efficiency of nanostructures is dependent on their size, surface charge, and shape [42]. The diversity of the characteristics of the metal nanoparticles relates to their toxicity. Some authors believe that the toxicity of metallic nanoparticles is related to the production of reactive oxygen species (ROS), which depends on the particle size, shape, surface area, and chemistry [43]. Some studies have reported the creation of ROS as $\mathrm{O}_{2}$ in $\mathrm{TiO}_{2}, \mathrm{ZnO}, \mathrm{V}_{2} \mathrm{O}_{5}, \mathrm{CeO}_{2}, \mathrm{Fe}_{2} \mathrm{O}_{3}$, and $\mathrm{Al}_{2} \mathrm{O}_{3}$ under photoillumination [44]. Thus, the toxicity of MeNPs not only affects humans and the environment, the toxicity is also produced in microorganisms and can influence the antibiotic, biocidal, antifungal, and antiviral activity [43]. As such, MeNPs are proposed as a promising antiviral agent. 


\section{Antiviral Activity of Metallic Nanoparticles}

Viruses are submicroscopic particles made out of RNA or DNA and a capsid composed of proteins. They only multiply in the host cells at the expense of the cells' metabolism [45]. The virus multiplication cycle involves several events: the entry into the cells, the synthesis of the genome and viral proteins, the assembly of viral components, and the viral output of infected cells [46]. Consequently, if a compound can inhibit one or more stages of the virus cycle, it can be considered an antiviral agent [46]. Due to the ability of MeNPs to intervene in some steps of virus replication, they have been studied for antiviral therapy in recent decades [47]. The use of nanoparticles against viruses focuses on the detection or treatment of diseases, such as the human immunodeficiency virus, hepatitis A, B, and C (HAV, HBV, HCV), influenza virus, and herpes virus 1 and 2 (HSV-1, HSV-2) [48]. Studies have been developed along two lines: the antiviral activity of (1) functionalized MeNPs or (2) pure or non-functionalized nanoparticles [47]. Regarding the latter, the main compounds evaluated are gold and silver, as well as some metal oxide nanoparticles, such as iron oxide, zinc oxide, and titanium dioxide. Notably, several studies have demonstrated the antiviral activity of metal nanoparticles against human viruses. It seems that silver nanoparticles display a broad spectrum of antiviral activity against viral infections from the Retroviridae, Herpesviridae, Paramyxoviridae, Poxviridae, Orthomyxoviridae, Arenaviridae, and Hepadnaviridae families [48]. Within the most important studies, AgNPs have shown antiviral activity against influenza, foot-and-mouth disease virus, HIV-1, herpex simplex, hepatitis B, HSV-1, respiratory syncytial virus, H1N1, and H5N1 influenza A virus [49-52]. The mechanisms of action used by silver nanoparticles against viruses are the interaction with gp120, competition for the binding of the virus to the cell, inactivation of the virus particles before entry, interaction with double-stranded DNA, and binding with viral particles [48]. Gold/copper sulfide core-shell nanoparticles (Au/CuSNPs) induce viral capsid protein degradation and capsid damage [53]. Furthermore, the antiviral effect of metallic nanoparticles is due to a synergistic effect with other chemical compounds. Selenium nanoparticles (SeNPs) enhance the anti-EV71 activity of oseltamivir in the human astrocytoma cell model [54].

In the case of metal oxide nanoparticles, Levina et al. [55] reported that $\mathrm{TiO}_{2} \cdot$ polylysine (PL)-DNA nanocomposites could be successfully used for the highly efficient and site-specific inhibition of influenza A viruses of different subtypes. Cui et al. [56] reported the inactivation of H9N2 avian influenza virus in cells exposed to an anatase nano- $\mathrm{TiO}_{2}$ solution under UV irradiation at $365 \mathrm{~nm}$. The above suggests that MeNPs under photoillumination induce the production of radicals, which makes them toxic. However, Mazurkova et al. [57] reported that $\mathrm{TiO}_{2}$ nanoparticles inactivate the influenza virus independent of illumination with light, which indicates that antiviral activity is not related to photocatalytic effects. The inactivation of the virus likely occurs due to the union and destruction of the virus envelope by nanoparticles. In contrast, in silico studies of the interaction of $\mathrm{TiO}_{2}$ nanoparticles with twenty amino acids in aqueous solution indicate that charged amino acids play a dominant role during the process of bonding to the $\mathrm{TiO}_{2}$ surface, with basic and acidic residues being preferred over those that are not loaded. When calculating the mean potential strength, the amino acid Arg is prone to direct bonding on the surface of the NPs. In contrast, Lys needs to overcome a free energy barrier of $\sim 2 \mathrm{kT}$. Moreover, acid residues tend to form hydrogen bonds between their side chains and the $\mathrm{TiO}_{2}$ surface, thus showing an indirect link [58].

In the case of the HSV-1 virus, partially negatively charged $\mathrm{ZnO}$ nanoparticles effectively trap virions through a novel virostatic mechanism that renders them incapable of entering human corneal fibroblasts [59]. Tavakoli et al. [60] determined the inhibitory effects of zinc oxide nanoparticles (ZnONPs) and polyethylene glycol (PEG)-coated ZnONPs (ZnO-PEG-NPs) on HSV-1. The results indicated that some changes in the nanoparticles, such as the PEGylation of $\mathrm{ZnO}$ nanoparticles, decrease the cytotoxicity and increase the antiviral activity against HSV-1. On the other hand, $\mathrm{ZnO}$ nanoparticles interact with the Chikungunya virus, showing an antiviral effect. Other metal oxide nanoparticles, such as tin oxide $\left(\mathrm{SnO}_{2}\right)$ nanowires, have demonstrated antiviral activity as an effective treatment 
against HSV-1 infection, where these nanoparticles carry negatively charged structures that compete with the HSV-1 attachment to cell-bound heparan sulfate (HS), avoiding cell spread [34].

\section{Antiviral Activity of MeNPs in Plants}

Plant viruses are a challenge for the production of vegetables. Studies have focused on the use of nanoparticles for the management of plant diseases; however, research aimed at combatting viral diseases is still in its beginning stages. The antiviral mechanisms of MeNPs are not well understood but current available studies could provide evidence of the mechanisms involved. The antiviral activity of MeNPs has been demonstrated both in vitro and in vivo with different plants and is effective against positive- and negative-sense single-stranded RNA viruses (Table 1). Many authors describe the interaction of MeNPs with the surface of the virus as one step of the antiviral mechanism. Cai et al. [9] reported on the antiviral activity of $\mathrm{ZnONPs}$ and $\mathrm{SiO}_{2} \mathrm{NPs}$ against tobacco mosaic virus (TMV) in vitro. The results of this work suggest a direct inactivation of TMV by MeNPs due to the interaction with envelope glycoproteins, which causes the direct injury of TMV shell proteins, TMV aggregation, and even fracture. TMV particles treated with $\mathrm{Fe}_{3} \mathrm{O}_{4} \mathrm{NPs}$ display the same aggregation and fracture; furthermore, direct interactions between $\mathrm{Fe}_{3} \mathrm{O}_{4} \mathrm{NPs}$ and TMV particles lead to larger particle sizes [61]. AgNPs can also bind to coat protein virus particles of the tomato mosaic virus (ToMV) and potato virus Y (PVY) [62]. Meanwhile, Alkubaisi and Aref [63] showed that AuNPs cause damage to the virus-like particles (VLPs) of the barley yellow dwarf virus-PAV, where they observed puffed and deteriorated VLPs decorated with AuNPs, as well as destroyed and vanished particles, using TEM. 
Table 1. Antiviral activity of metal and metal and metal oxide nanoparticles.

\begin{tabular}{|c|c|c|c|c|c|}
\hline Nanoparticle & Size & Plant & Pathogen & Effect & References \\
\hline Silver nanoparticles (AgNPs) & $10-20 \mathrm{~nm}$ & Cymopsis tetragonaloba & Sunhemp rosette virus (SHRV) & $\begin{array}{l}\text { Complete suppression of } \\
\text { the disease }\end{array}$ & [64] \\
\hline AgNPs & $77 \mathrm{~nm}$ & Vicia faba & Bean yellow mosaic virus (BYMV) & $\begin{array}{c}\text { Decrease in virus } \\
\text { concentration, percentage of } \\
\text { infection, and disease severity } \\
\text { Reduction in lesions on } \\
\text { infected leaves }\end{array}$ & [65] \\
\hline Schiff base nanosilver NPs & & Nicotiana tabacum & Tobacco mosaic virus (TMV) & $\begin{array}{l}\text { Reduction of the harm of } \\
\text { TMV to tobacco }\end{array}$ & {$[66]$} \\
\hline AgNPs & $12 \mathrm{~nm}$ & Solanum tuberosum & Potato virus Y (PVY) & Resistance to virus infection & [67] \\
\hline $\begin{array}{l}\text { Graphene oxide-silver NPs } \\
\text { (GO-AgNPs) }\end{array}$ & $3050 \mathrm{~nm}$ & Lactuca sativa & Tomato bushy stunt virus (TBSV) & $\begin{array}{l}\text { Decrease in virus } \\
\text { concentration, infection } \\
\text { percentage, and } \\
\text { disease severity }\end{array}$ & [68] \\
\hline AgNPs & $12.6 \pm 5 \mathrm{~nm}$ & Solanum tuberosum L. cv. Spunta & Tomato spotted wilt virus (TSWV) & $\begin{array}{l}\text { Decrease in TSWV infectivity } \\
\text { and produces an inhibitory } \\
\text { effect in local lesions }\end{array}$ & [69] \\
\hline AgNPs & - & Solanum lycopersicum & Tomato mosaic virus (ToMV) & $\begin{array}{l}\text { Reduction in disease severity } \\
\text { and virus infection }\end{array}$ & [62] \\
\hline AgNPs & - & Solanum lycopersicum & Potato virus Y (PVY) & $\begin{array}{l}\text { Reduction in disease severity } \\
\text { and virus infection }\end{array}$ & [62] \\
\hline Gold NPs (AuNPs) & & Hordeum vulgare & Barley yellow mosaic virus (BaYMV) & $\begin{array}{l}\text { Dissociation of virus particle } \\
\text { in vitro }\end{array}$ & [70] \\
\hline AuNPs & 3.151 to $31.67 \mathrm{~nm}$ & Hordeum vulgare & $\begin{array}{l}\text { Barley yellow dwarf virus-PAV } \\
\text { (BYDV-PAV) }\end{array}$ & $\begin{array}{l}\text { Destroys gold barley yellow } \\
\text { dwarf virus and eliminates } \\
\text { virus infectivity hazards }\end{array}$ & [63] \\
\hline Titanium dioxide $\mathrm{NPs}\left(\mathrm{TiO}_{2} \mathrm{NPs}\right)$ & $\sim 3-5 \mu \mathrm{m}$ & Vicia faba L. Fabaceae & Broad bean stain virus (BBSV) & Reduction in disease severity & [71] \\
\hline $\mathrm{TiO}_{2} \mathrm{NPs}$ & $20 \mathrm{~nm}$ & Nicotiana benthamiana & Turnip mosaic virus (TuMV) & $\begin{array}{l}\text { Effectively limits viral } \\
\text { infection and replication }\end{array}$ & [72] \\
\hline Zinc oxide NPs (ZnONPs) & $18 \mathrm{~nm}$ & Nicotiana benthamiana & Tobacco mosaic virus (TMV) & $\begin{array}{l}\text { Suppression of the speed of } \\
\text { TMV invasion }\end{array}$ & [9] \\
\hline
\end{tabular}


Table 1. Antiviral activity of metal and metal and metal oxide nanoparticles.

\begin{tabular}{|c|c|c|c|c|c|}
\hline Nanoparticle & Size & Plant & Pathogen & Effect & References \\
\hline ZnONPs & - & Solanum melongena & Cucumber mosaic virus (CMV) & $\begin{array}{l}\text { Disease severity and } \\
\text { incidence were } \\
\text { significantly reduced }\end{array}$ & [73] \\
\hline Silicon dioxide $\mathrm{NPs}\left(\mathrm{SiO}_{2} \mathrm{NPs}\right)$ & - & Cucumis sativus & Papaya ringspot virus (PRSV) & $\begin{array}{l}\text { Reduction in disease severity } \\
\text { and virus accumulation }\end{array}$ & [74] \\
\hline $\mathrm{SiO}_{2} \mathrm{NPs}$ & $100 \mathrm{~nm}$ & Solanum lycopersicum & $\begin{array}{l}\text { Tomato yellow leaf curl virus } \\
\text { (TYLCV) }\end{array}$ & $\begin{array}{l}\text { Reduced disease severity and } \\
\text { TYLCV concentration }\end{array}$ & [75] \\
\hline $\mathrm{SiO}_{2} \mathrm{NPs}$ & $20 \mathrm{~nm}$ & Nicotiana tabacum & Tobacco mosaic virus (TMV) & $\begin{array}{l}\text { Suppression of the speed of } \\
\text { TMV invasion }\end{array}$ & [9] \\
\hline Iron oxide $\mathrm{NPs}\left(\mathrm{Fe}_{2} \mathrm{O}_{3} \mathrm{NPs}\right)$ & $40-100 \mathrm{~nm}$ & Nicotiana tabacum & Turnip mosaic virus (TuMV) & $\begin{array}{l}\text { Effectively limits viral } \\
\text { infection and replication }\end{array}$ & [72] \\
\hline $\mathrm{Fe}_{3} \mathrm{O}_{4} \mathrm{NPs}$ & $0.19 \mathrm{~nm}$ & Nicotiana benthamiana & Tobacco mosaic virus (TMV) & & [9] \\
\hline Nickel oxide NPs (NiONPs) & 15 to $20 \mathrm{~nm}$ & Cucumis sativus & Cucumber mosaic virus (CMV) & $\begin{array}{l}\text { Reduces disease severity and } \\
\text { CMV concentration }\end{array}$ & [76] \\
\hline Cerium oxide $\mathrm{NPs}\left(\mathrm{CeO}_{2} \mathrm{NPs}\right)$ & - & $\begin{array}{l}\text { Datura stramonium and } \\
\text { Nicotiana tabacum }\end{array}$ & Tobacco mosaic virus (TMV) & Reduction in virus symptoms & [77] \\
\hline
\end{tabular}


In vivo studies of the effectiveness of MeNPs against viral infections in the Solanaceae, Asteraceae, Poaceae, Fabaceae, and Cucurbitaceae families have also been conducted. The application of MeNPs in plants interferes with the reproduction of viruses through different mechanisms. Furthermore, nanoparticles affect the diseases caused by viruses. $\mathrm{CeO}_{2} \mathrm{NPs}$ inhibits the reproduction of viruses by penetrating the TMV-infected leaf segment of Datura stramonium and Nicotiana tabacum through the vascular system and inhibits reproduction [77]. Graphene-based silver nanocomposites exhibit potent activity against tomato bushy stunt virus (TBSV) in lettuce, decreasing the virus concentration and disease severity [68]. The antiviral activity of the NPs was observed in both the foliar application and the soil supplementation. Cucumis sativus infected with papaya ringspot virus (PRSV) and treated with $\mathrm{SiO}_{2} \mathrm{NPs}$ via soil supplementation produced a significant reduction in disease symptoms [74]. Application of $\mathrm{TiO}_{2} \mathrm{NPs}$ using sprays and soil drenches after $24 \mathrm{~h}$ of broad bean strain virus (BBSV) inoculation in faba bean plants causes a dramatic decrease in BBSV. The antiviral effect and the responses of the plants depend on the treatment time, that is, whether they are applied before, along with, or after the viral infection. Elbeshehy et al. [65] studied the effect that AgNPs synthesized by the bacteria Bacillus pumilus, Bacillus persicus, and Bacillus licheniformis had on yellow bean mosaic virus. A post-infection treatment $24 \mathrm{~h}$ after virus exposition prevented all negative symptoms caused by the virus. However, plants treated with the AgNPs and infected simultaneously showed weak BYMV symptoms, and a pre-infection treatment $72 \mathrm{~h}$ before inoculation showed no effect on the virus concentration and disease severity.

Chenopodium amaranticolor plants showed the most significant antiviral effect against tomato spot wilt virus (TSWV) when the AgNPs were sprayed $24 \mathrm{~h}$ after inoculation. Plants sprayed after inoculation showed a weak infection, and plants sprayed before inoculation displayed weak inhibition [69]. El-shazly et al. [67] reported a decrease in virus concentration and disease percentage for potato plants sprayed with AgNPs $24 \mathrm{~h}$ after inoculation with tomato bushy stunt virus (TBSV) [67]. On the other hand, Cymopsis tetragonaloba leaves sprayed with AgNPs and sunhemp rosette virus (SHRV) showed complete suppression of the disease by inactivating virus replication [64]. Other authors presented studies where there was antiviral activity when NPs were applied pre-inoculation. A reduction in the severity of the virus was also reported for cucumber plants treated with nickel oxide NPs and for tomato plants sprayed with silica nanoparticles 1 day before tomato yellow leaf curl virus (TYLCV) inoculation [75]. A mixture of AgNPs and salicylic acid (SA) applied before 3 and 7 days of virus infection shows a synergistic antiviral effect against TBSV compared to individual AgNPs and SA treatments [67]. The above shows the ability of NPs mixed with other compounds to present a synergistic effect. Some authors suggest that MeNPs activate the immune system of plants $[9,61,72,76]$. To evaluate the protective effect of nanoparticles in tobacco plants (Nicotiana benthamiana) contra TMV, Cai et al. [9] applied $\mathrm{ZnO}$ and $\mathrm{SiO}_{2} \mathrm{NPs} 3,7$, and 12 days before inoculating with the virus; the 12-day treatment exhibited high antiviral effects and more efficiently prevented TMV from spreading to newly emerged leaves. Tobacco pretreated with $\mathrm{Fe}_{2} \mathrm{O}_{3}$ or $\mathrm{TiO}_{2} \mathrm{NPs}$ for 21 days showed antiviral properties, decreased the amount of the viral protein of turnip mosaic virus (TuMV), which the authors suggest could be related to the fact that the NPs interfered with either protein biosynthesis or post-translational modification processes in the virus, and activated defense mechanisms [72]. AgNPs sprayed on infected tomatoes for 7 days before inoculation with ToMV and PVY reduced the disease severity and virus concentration because the NPs were bound to the virus and inhibited virus replication [62]. Nicotiana benthamiana leaves pretreated with $\mathrm{Fe}_{3} \mathrm{O}_{4} \mathrm{NP}$ for 12 days showed high resistance to TMV, which is even more potent than lentinan. Furthermore, the authors reported that NahG transgenic plants, i.e., plants that degrade SA, did not reduce virus accumulation after 12 days of $\mathrm{Fe}_{3} \mathrm{O}_{4} \mathrm{NP}$ treatment. The above indicates the generation of plant resistance induced by $\mathrm{Fe}_{3} \mathrm{O}_{4} \mathrm{NPs}$ was mainly due to the upregulation of SA synthesis [61]. Some complexes with metals, for example, chitosan Schiff base nanosilver (S-cos-Ag), significantly reduced the number of lesions in TMV-infected tobacco leaves, inducing TMV resistance and promoting the tobacco's immunity [66]. These studies support the idea of Cai et al. [61], which states that the use of MeNPs as antivirals in plants is due not only 
through the inactivation of viruses and inhibition of multiplication but also the activation of plant defense mechanisms that leads to plant immunity and growth response, in which the antioxidant system, resistance genes, and plant hormones participate (Figure 1).

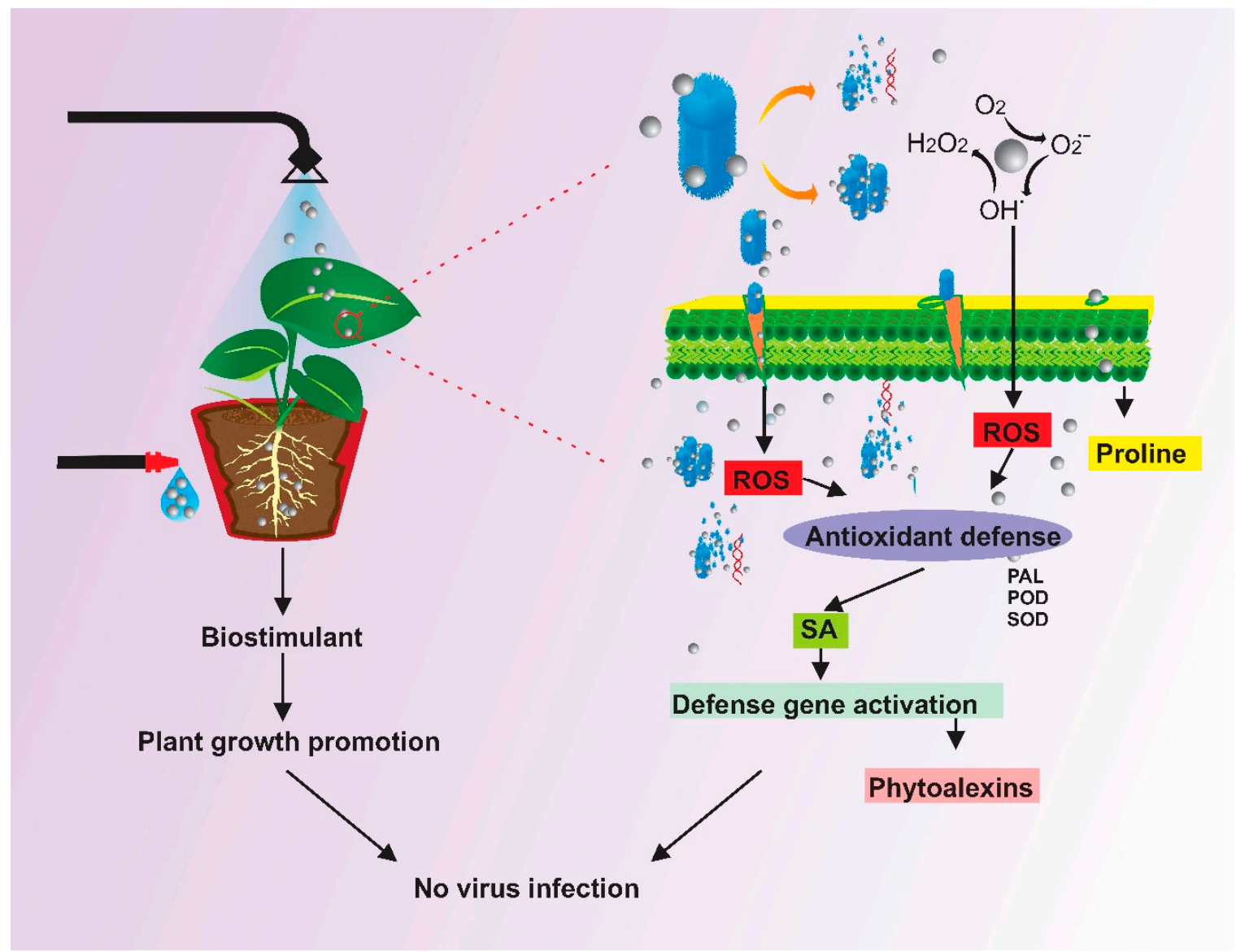

Figure 1. Antiviral mechanism of metal and metal oxide nanoparticles in plants. PAL: phenylalanine ammonia-lyase; POD: peroxidase; ROS: reactive oxygen species; SA: salicylic acid; SOD: superoxide dismutase.

\section{Viral Inhibition via Plant Defense Induction Using NPs}

\subsection{Antioxidant System}

The general plant response to stress is the increase in reactive oxygen species (ROS) levels, which limits pathogen ingress and distribution and induces systemic and local defense responses, such as the activation of pathogenesis-related (PR) genes [9]. Many biotic and abiotic stimuli induce ROS production in plants. When ROS levels $\left(\mathrm{O}_{2}, \mathrm{H}_{2} \mathrm{O}_{2}, \mathrm{OH}\right.$, and $\left.1 \mathrm{O}_{2}\right)$ are higher than the threshold, they generate oxidative products and the balance between ROS and antioxidants is interrupted. The antioxidant system allows plants to counterbalance the effect of oxidants. Superoxide dismutase (SOD) is the first line of defense and is responsible for the transformation of $\mathrm{O}_{2}$ into $\mathrm{H}_{2} \mathrm{O}_{2}$ and water [78,79]. The antioxidant system also consists of enzymes, such as catalase (CAT), ascorbate peroxidase (APX), and guiacol peroxidase (GPX) [79]. Depending on the type of MeNPs, the concentration, and the type of culture, MeNPs interfere with cellular redox homeostasis by either inducing or reducing the occurrence of oxidative stress [78]. Studies have shown that the application of $\mathrm{TiO}_{2}, \mathrm{CeO}_{2}, \mathrm{ZnO}, \mathrm{CuO}, \mathrm{Ag}, \mathrm{NiO}, \mathrm{Al}_{2} \mathrm{O}_{3}, \mathrm{CoFe}_{2} \mathrm{O}_{4}, \mathrm{Fe}_{3} \mathrm{O}_{4}$, and $\gamma-\mathrm{Fe}_{2} \mathrm{O}_{3} \mathrm{NPs}$ can induce the repression of oxidative stress and the antioxidant system in various crops [78]. Cai et al. [61] studied the foliar application of $\mathrm{Fe}_{3} \mathrm{O}_{4} \mathrm{NPs}$ treatment on tobacco leaves; the results show that this treatment induced 
the production of ROS, which could be related to the induction of resistance in tobacco. $\mathrm{ZnO}$ and $\mathrm{SiO}_{2} \mathrm{NPs}$ accumulated hydrogen peroxide, even without the presence of the virus. On the other

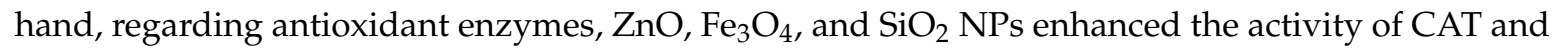
peroxide (POD) [9,61]. Other enzymes were expressed in the presence of the virus. $\mathrm{SiO}_{2} \mathrm{NP}$-treated cucumber plants showed pox and pal gene expression 1 day after PRSV inoculation [74]. Cucumber plants treated with NiONPs after four days of cucumber mosaic virus (CMV) inoculation increased pod gene expression [76]. Tomato plants treated with AgNPs and inoculated with ToMV or PVY showed a significant increase in the activity of the antioxidant enzymes POD and polyphenol oxidase (PPO) [62].

\subsection{Plant Hormones and Pathogenesis-Related Proteins}

Plant resistance operates through an elaborate defense mechanism network, in which salicylic acid (SA), jasmonic acid (JA), and ethylene (ET) regulate the defense pathways to trigger appropriate responses. Other plant growth hormones with the ability to modulate defense responses include gibberellin (GA), auxin (indole-3-acetic acid (IAA)), cytokinin (CK), brassinosteroids (BRs), abscisic acid (ABA), and strigolactone (SL). The crosstalk during multiple plant hormone signals regulates the balance between plant growth and defense. Different types of stress in different hormonal pathways are known to be up or down-regulated hormonal pathways; for example, nanoparticles influence the hormonal balance in plants [80]. Arabidopsis thaliana exposed to CuONPs elevates the content of SA and JA, as well as the transcription of genes involved in their signaling routes [81]. Furthermore, the mixture of chitosan polyvinyl alcohol hydrogels (Cs-PVA) and copper nanoparticles (CuNPs) overexpresses the JA gene in tomato plants under salt stress [82]. $\mathrm{Fe}_{3} \mathrm{O}_{4} \mathrm{NPs}$ elevates the ABA and SA levels in Nicotiana benthamiana, while there was no change in the level of JA [61]. The above discussion suggests that the expression of a particular hormone depends on the specific interaction between the plant and MeNPs, including the dose and the time of application.

Plants treated with AgNPs also increase other hormones, such as CK in Capsicum annuum L [83]. IAA and ABA decreased in cotton plants after $\mathrm{CeO}_{2} \mathrm{NPs}$ exposition [84]. Small doses of ZnONPs produce an elevation in CK biosynthesis, and at moderate and high doses, ZnONPs function as stressors that stimulate plant defenses, up-regulating the levels of the stress hormones ABA and SA [81]. Plants use mechanisms to modulate plant growth and to regulate the plant's defense against pathogens, including viruses. TMV-infected tobacco with $\mathrm{Fe}_{2} \mathrm{O}_{3}$ and $\mathrm{TiO}_{2} \mathrm{NPs}$ impacts the phytohormone levels of zeratin riboside, abscisic acid, and brassinoid [72]. TuMV-infested $N$. benthamiana leaves treated with $\mathrm{Fe}_{2} \mathrm{O}_{3}$ and $\mathrm{TiO}_{2}$ NPs increased the concentration of phytohormones zeatin ribose (ZR) and BR, and decreased the ABA concentration. Furthermore, infected tomato plants treated with AgNPs increase the proline content [62].

Pathogenesis-related proteins are components of a plant's innate immune system and are part of the diagnostic molecular markers of defense signaling pathways. The expression of the genes PR1, $P R 2$, and PR5 indicates the activation of an SA signaling pathway [85]. Uninfected Nicotiana benthamiana plants treated with $\mathrm{ZnO}$ and $\mathrm{SiO}_{2} \mathrm{NPs}$ up-regulate SA-inducible pathogenesis-related genes $P R 1$ and PR2 [9], where the same effect is reported due to the impact of $\mathrm{Fe}_{3} \mathrm{O}_{4} \mathrm{NPs}$ [61]. Cucumis sativus treated with $\mathrm{SiO}_{2} \mathrm{NPs}$ and also inoculated with PRSV (1 dpi) induce the expression of PR1 [74]. Cucumber plants also increase PR1 after 2 and 4 dpi with a CMV infection [76].

\subsection{Secondary Metabolite Production}

There have been a few studies related to the impact of MeNPs on the secondary metabolism of plants, but the mechanism is still not well understood. Some authors indicate that ROS production due to the interaction with NPs will likely interfere with the secondary plant metabolism [86]. Phenylalanine ammonia-lyase (PAL) is an essential enzyme in a plant's defense as a branch point between primary and secondary metabolism. PAL catalyzes the non-oxidative deamination of phenylalanine to trans-cinnamate. In the phenylpropanoid pathway, it is also involved in the biosynthesis of SA. It is a SA/JA-inducible enzyme and is also produced by abiotic and biotic stress. Treatments with 
$\mathrm{SiO}_{2} \mathrm{NPs}$ increase JA-inducible PAL in plants infected with PRSV [74] and in cucumber plants infected with CMV and treated with NiONPs [76]. CuONPs upregulate the pal gene and enhance phytochemicals (i.e., glucosinolates and phenolic compounds) in Brassica rapa [87]. Tobacco plants show PAL enzyme activity, as well as phenolic compound and flavonoid accumulation, when ZnONPs are applied [88]. Furthermore, CuNPs have a beneficial effect on the accumulation of bioactive compounds in Moringa oleifera leaves [89]. ZnONPs also increase the total phenolic and anthocyanin content in potato plants [90].

\section{Effect of MeNPs as Biostimulants in Virus-Infected Plants}

According to du Jardin [91], plant biostimulants are substances and materials, other than nutrients and pesticides, that when applied to a plant, seeds, or growing substrates in specific formulations, can modify the physiological processes of plants in a way that provides potential benefits to growth, development, and defense responses. Depending on the nanoparticle and the state of the plant, NPs provide a positive (eustress) or negative (distress) impact. [80,92]. Studies on healthy tobacco plants treated with $\mathrm{SiO}_{2}, \mathrm{ZnO}$, and $\mathrm{Fe}_{2} \mathrm{O}_{3} \mathrm{NPs}$ increased tobacco growth [9,61]. Therefore, this biostimulant effect can cause eustress in healthy and also in stressed plants, for example plants infected with a virus, since it counteracts the destructive effects they cause. Infected cucumber plants, which were applied to NiONPs by foliar spray and soil drench showed higher fresh and dry weights and an increase in the number of leaves [76]. TuMV-infested tobacco that was foliar-spray-treated with $50 \mathrm{mg} / \mathrm{L} \mathrm{of} \mathrm{TiO}_{2}$ and $\mathrm{FeO}_{3} \mathrm{NPs}$ increased in fresh and dry weight, while the treatment of $200 \mathrm{mg} / \mathrm{L}$ had no effect compared to the plants without a nanoparticle treatment [72]. The application of AgNPs to PVY-infected tubers improves the quality parameters compared to infected plants without treatment. The above may be due to the induction of resistance or the impact of NPs on virus entry [67].

\section{Nanoparticles against Plant Viral Pathogens}

There are several applications of nanotechnology in agriculture, for example (1) in nutrition having beneficial effects due to the production of primary and secondary metabolites; (2) defense against pathogens, as antimicrobial, antifungal, and antiviral agents or as protectants and nanocarriers for insecticides, fungicides, herbicides, and RNA-interference molecules; and (3) the management of the maturation process of fruits in pre- and post-harvest stages [93].

The current use of insecticides is very limited, even in developed countries, due to the problems they cause and because a decrease in a vector population does not necessarily achieve a proportional reduction in the incidence of the virus. Other issues are: (a) the treatment cost, (b) the potential damage to natural enemies of vectors, (c) risk to the environment, and (d) the potential damage to human health [94]. The use of nanoparticles has many advantages due to its low cost, high stability, incorporation of both hydrophilic and hydrophobic substances, secure handling, and they are renewable; the physicochemical properties can also be controlled. The current rate of development of antiviral agents is promising due to the constant appearance of emerging or re-emerging viruses [48]. Due to the above, the use of metal nanoparticles is an exciting opportunity for novel antiviral therapy uses in crops; however, it is essential to take into account its toxicity and manage the application doses. Many of the MeNPs and MoNPs do not present toxicity to humans at the concentrations used as antimicrobials, and many of these concentrations are also those used to activate the antiviral activity, which is an advantage for their large-scale use [95]. Furthermore, the concentrations at which they show antiviral activity do not have negative impacts on plants and sometimes even show a positive or eustress effect.

However, despite the advantages that potentially harmful aspects of the MeNPs present must be considered. Fate should be monitored as well as their potential toxicity and levels of overdosing. Plants can absorb and translocate MeNPs to different parts depending on their bio-ability, concentration, solubility, and exposure time [96]. It is essential to take the doses and the time of application into account and monitor the phenological status of the plant to determine whether they are displaying 
any negative effects. It is also necessary to establish the process of accumulation of the nanoparticles, especially in the edible parts of the plant, and even the effect of MeNPs at the nutraceutical level, such that they are not toxic and may even have a beneficial impact for consumers. Although there are no reports related to the time in which MeNPs remain in the plants, nanoparticles can accumulate in fruits and seeds. Studies have reported the transgenerational effects of $\mathrm{CeO}_{2} \mathrm{NPs}$ in second-generation seedlings. Those were grown with seeds from parental plants treated with $10 \mathrm{mg} / \mathrm{L} \mathrm{CeO}_{2} \mathrm{NPs}_{\mathrm{s}}$ showing more cerium compared to non-treated plants [97]. MeNPs are taken up and accumulate in plants that are food for insects, animals, or humans entering the food chain, and some of them can damage some biological entities of the food chain. Studies have reported that crickets fed $\mathrm{NP} \mathrm{CeO}_{2}$-exposed zucchini leaves accumulate more $\mathrm{Ce}$ than bulk exposed insects. The authors indicate that the accumulation of $\mathrm{CeO}_{2} \mathrm{NPs}$ in zucchini results in trophic transfer and can contaminate the food chain [98].

The nanoparticles, once used, are released into the environment. Their use and release into the soil have an adverse effect on soil microbial ecology, modifying their number, biomass, activity, and diversity. MeNPs such as $\mathrm{ZnO}, \mathrm{TiO}_{2}, \mathrm{CeO}_{2}$, and $\mathrm{Fe}_{3} \mathrm{O}_{4} \mathrm{NPs}$ affect soil enzyme activities and change soil bacterial communities [99]. Besides, $\mathrm{CeO}_{2} \mathrm{NPs}$ have been found to compromise soil fertility [100]. Because of this, it is a critical point for FDA approval of the detailed knowledge of the biodegradation rate [101]. Some polymer encapsulated metal oxide nanoparticles have a degradation time in different media variables from a few days to months [101]. Knowing the biodegradation time of nanoparticles and the damage that may be caused to the potentially susceptible biota, the generation of the application management program to reduce the potential toxicity in the biological communities involved should be an important commitment.

It has been reported that nanoparticle formulations are 10-100 times more effective than traditional formulations to contend with similar problems. Some of these formulations can be used at the rate of $50 \mathrm{~mL}$ of nanoemulsions or $8 \mathrm{~g}$ per hectare [102]. Studies have reported antiviral activity of MeNPs at a maximum concentration of $200 \mu \mathrm{g} / \mathrm{mL}$; according to these data, it was established that the amount that could be used for virus control in agriculture is approx. $20-40 \mathrm{~g} / \mathrm{ha}$ for each application. The large-scale application of nanoparticles in agriculture requires mass production. The low-cost mass production of nanoparticles has gained much attention in industrial and academic circles [103]. Physical methods for the synthesis of nanoparticles are expensive, require strong material, toughness, and strength, and are difficult to facilitate on a large scale, while chemical methods are used in mass production; they could have a negative impact on the environment [104]. An alternative to the use of nanoparticles that harm the environment is an environmentally friendly green approach for their synthesis [105]. The production of MeNPs through biogenesis has advanced in aspects of profitability, and eco-friendly since bacteria, fungi, and plants are involved. However, there are other aspects to improve, green synthesis using plant extracts can be comparable to conventional methods, but mass production requires highly reactive substances or energy-consuming [106].

The ability to act by interfering with any of the stages of the infection to prevent the induction of virus symptoms, to be selective to avoid damaging the host, to have a broad spectrum, and have no harmful effects on the environment would be the requirements to finally achieve a curative antiviral chemical. One of the most promising strategies for the effective use of antivirals is to interfere with virus recognition and entry into the host [48]. Metallic and metal oxide nanoparticles appear to interfere with mammalian virus recognition and have the ability to interact with surface proteins through their interactions with viral envelope glycoproteins and glycoprotein receptors. In addition to their use in crops, MeNPs can be used to prevent viruses in seeds. In plants, vertical transmission through seeds is common. The mechanisms of transmission are through contamination of the seed coat or invasion of the seed embryo indirectly by infection of plant gametes before fertilization or directly from the mother plant to the embryonic tissue after fertilization [107]. The potential use of MeNPs as seed antivirals due to their antimicrobial properties and their size may limit the pathogen in the seed. MeNPs can also be applied in seedlings to avoid virus contamination [65]. In vitro culture represents the most successful approaches for virus eradication in seedling [27]. The use of nanoparticles as compounds to control 
the virus can be an alternative to antiviral compounds. On the other hand, studies have reported that the antiviral activity of MeNPs is higher when applied in cultures before infection [9,61]. Therefore, the use of MeNPs is proposed as a preventive control that can be applied to early-stage plants, either to seeds or seedlings. These types of particles presents a wide range of infectious diseases. Preventive control will not only avoid infection by viral pathogens but also by fungi or bacteria [108].

\section{Conclusions}

The use of NPs has excellent potential to deal with the problem of virus-caused diseases in agriculture. It is necessary to establish precise complementary methodologies such that the technology is ready to be used without risks to the environment or consumers. Among this complementary knowledge, it is required to prescribe doses, the stage of phenological development of the plant to make the applications, and the precise types of NPs that produce the greatest advantages.

Author Contributions: M.V.-H. was responsible for reviewing the literature and writing the paper. I.T.-P. was responsible for managing the team and the conception of the research topic. R.G.G.-G., I.M.-B., R.V.O.-V., E.R.-G., and L.A.-J. were in charge of reviewing the manuscript. All authors have read and agreed to the published version of the manuscript.

Funding: I. Torres Pacheco acknowledges CONACYT Ciencia Básica for grant A1-S-33677.

Acknowledgments: M.V.-H. acknowledges Consejo Nacional de Ciencia y Tecnología (CONACYT) for providing grant 401146.

Conflicts of Interest: The authors declare that the research was conducted in the absence of any commercial or financial relationships that could be construed as a potential conflict of interest.

\section{References}

1. Khan, I.; Saeed, K.; Khan, I. Nanoparticles: Properties, Applications and Toxicities. Arab. J. Chem. 2017. [CrossRef]

2. Yih, T.C.; Al-Fandi, M. Engineered nanoparticles as precise drug delivery systems. J. Cell. Biochem. 2006, 97, 1184-1190. [CrossRef]

3. Stankic, S.; Suman, S.; Haque, F.; Vidic, J. Pure and multi metal oxide nanoparticles: Synthesis, antibacterial and cytotoxic properties. J. Nanobiotechnol. 2016, 14, 73. [CrossRef]

4. Klębowski, B.; Depciuch, J.; Parlińska-Wojtan, M.; Baran, J. Applications of Noble Metal-Based Nanoparticles in Medicine. Int. J. Mol. Sci. 2018, 19, 4031. [CrossRef]

5. Asghari, F.; Jahanshiri, Z.; Imani, M.; Shams-Ghahfarokhi, M.; Razzaghi-Abyaneh, M. Chapter 10Antifungal nanomaterials: Synthesis, properties, and applications. In Nanobiomaterials in Antimicrobial Therapy-Applications of Nanobiomaterials; William Andrew Publishing: Kidlington, Oxford, UK, 2016; pp. 343-383. ISBN 978-0-323-42864-4.

6. Morais, M.; Martins, V.; Steffens, D.; Pranke, P.; Costa, J.A. Biological Applications of Nanobiotechnology. J. Nanosci. Nanotechnol. 2014, 14, 1007-1017. [CrossRef]

7. Singh, L.; Kruger, H.G.; Maguire, G.E.M.; Govender, T.; Parboosing, R. The role of nanotechnology in the treatment of viral infections. Ther. Adv. Infect. Dis. 2017, 4, 105-131. [CrossRef]

8. Díez-Pascual, A.M. Antibacterial Activity of Nanomaterials. Nanomaterials 2018, 8, 359. [CrossRef]

9. Cai, L.; Liu, C.; Fan, G.; Liu, C.; Sun, X. Preventing viral disease by ZnONPs through directly deactivating TMV and activating the plant immunity in Nicotiana benthamiana. Environ. Sci. Nano. 2019. [CrossRef]

10. Halevas, E.; Pantazaki, A. Copper Nanoparticles as Therapeutic Anticancer Agents. Nanomed. Nanotechnol. J. 2018, 2, 119.

11. Tripathi, M.; Kumar, S.; Kumar, A.; Tripathi, P.; Kumar, S. Agro-nanotechnology: A Future Technology for Sustainable Agriculture. Int. J. Curr. Microbiol. Appl. Sci. 2018, 7, 196-200.

12. Prasad, R.; Bhattacharyya, A.; Nguyen, Q.D. Nanotechnology in Sustainable Agriculture: Recent Developments, Challenges, and Perspectives. Front. Microbiol. 2017, 8, 1014. [CrossRef]

13. Roossinck, M.J. Plant virus ecology. PLoS Pathog. 2013, 9, e1003304. [CrossRef] 
14. Bernardo, P.; Charles-Dominique, T.; Barakat, M.; Ortet, P.; Fernandez, E.; Filloux, D.; Hartnady, P.; Rebelo, T.A.; Cousins, S.R.; Mesleard, F.; et al. Geometagenomics illuminates the impact of agriculture on the distribution and prevalence of plant viruses at the ecosystem scale. ISME J. 2018, 12, 173-184. [CrossRef]

15. Chauhan, P.; Singla, K.; Rajbhar, M.; Singh, A.; Das, N.; Kumar, K. A systematic review of conventional and advanced approaches for the control of plant viruses. J. Appl. Biol. Biotechnol. 2019, 7, 89-98. [CrossRef]

16. Hill, J.; Whitham, S. Control of Virus Diseases in Soybeans. Adv. Virus Res. 2014, 90, 355-390. [CrossRef]

17. Almasi, M.A.; Almasi, G. Colorimetric immunocapture loop mediated isothermal amplification assay for detection of Impatiens necrotic spot virus (INSV) by GineFinder ${ }^{\mathrm{TM}}$ dye. Eur. J. Plant Pathol. 2018, 150, 533-538. [CrossRef]

18. Xiang, Y.; Nie, X.; Bernardy, M.; Liu, J.; Su, L.; Bhagwat, B.; Dickison, V.; Holmes, J.; Grose, J.M.; Creelman, A.C. Genetic diversity of strawberry mild yellow edge virus from eastern Canada. Arch. Virol. 2020, 165, 923-935. [CrossRef]

19. Fernando, S.S.N.; Gunasekara, C.; Holton, J. Antimicrobial Nanoparticles: Applications and mechanisms of action. SRI Lankan J. Infect. Dis. 2018, 8, 2. [CrossRef]

20. Parveen, S.; Wani, A.H.; Shah, M.; Devi, H.; Bhat, M.; Koka, J. Preparation, characterization and antifungal activity of iron oxide nanoparticles. Microb. Pathog. 2018, 115. [CrossRef] [PubMed]

21. Jones, R.A.C. Future Scenarios for Plant Virus Pathogens as Climate Change Progresses. In Advances in Virus Research; Elsevier Science: Amsterdam, The Netherlands, 2016; Volume 95, pp. 87-147.

22. Sarwar, M. Chapter 27-Insects as transport devices of plant viruses. In Applied Plant Virology: Advances, Detection, and Antiviral Strategies; Academic Press: Cambridge, MA, USA, 2020; pp. 381-402. ISBN 978-0-12-818654-1.

23. Ziegler-Graff, V. Molecular Insights into Host and Vector Manipulation by Plant Viruses. Viruses 2020, 12, 263. [CrossRef]

24. Bragard, C.; Caciagli, P.; Lemaire, O.; López-Moya, J.J.; MacFarlane, S.; Susi, P.; Torrance, L. Status and Prospects of Plant Viruses Control through Interference Vector Transmission. Annu. Rev. Phytopathol. 2013, 51, 177-201. [CrossRef] [PubMed]

25. Pechinger, K.; Chooi, K.M.; MacDiarmid, R.M.; Harper, S.J.; Ziebell, H. A New Era for Mild Strain Cross-Protection. Viruses 2019, 11, 670. [CrossRef] [PubMed]

26. Maruthi, M.N.; Whitfield, E.C.; Otti, G.; Tumwegamire, S.; Kanju, E.; Legg, J.P.; Mkamilo, G.; Kawuki, R.; Benesi, I.; Zacarias, A.; et al. A method for generating virus-free cassava plants to combat viral disease epidemics in Africa. Physiol. Mol. Plant Pathol. 2019, 105, 77-87. [CrossRef] [PubMed]

27. Wang, M.-R.; Cui, Z.-H.; Li, J.-W.; Hao, X.-Y.; Zhao, L.; Wang, Q.-C. In vitro thermotherapy-based methods for plant virus eradication. Plant Methods 2018, 14, 87. [CrossRef] [PubMed]

28. Singh, B. Effect of antiviral chemicals on in vitro regeneration response and production of PLRV-free plants of potato. J. Crop Sci. Biotechnol. 2015, 18, 341-348. [CrossRef]

29. Panattoni, A.; D'Anna, F.; Cristani, C.; Triolo, E. Grapevine vitivirus A eradication in Vitis vinifera explants by antiviral drugs and thermotherapy. J. Virol. Methods 2008, 146, 129-135. [CrossRef] [PubMed]

30. Maisaro, M.; Sugiharto, B.; Dewanti, P. The Effect of Concentration and Exposure Time Acyclovir for Elimination Sugarcane Mosaic Virus (SCMV) on The Apical Bud Culture of Sugarcane PS 881. J. ILMU DASAR 2017, 18, 31. [CrossRef]

31. Zhao, Y.; Yang, X.; Zhou, G.; Zhang, T. Engineering plant virus resistance: From RNA silencing to genome editing strategies. Plant Biotechnol. J. 2020, 18, 328-336. [CrossRef]

32. Sanchez-Dominguez, M.; Boutonnet, M.; Solans, C. A novel approach to metal and metal oxide nanoparticle synthesis: The oil-in-water microemulsion reaction method. J. Nanopart. Res. 2009, 11, 1823-1829. [CrossRef]

33. Rajput, V.; Minkina, T.; Behal, A.; Sushkova, S.; Mandzhieva, S.; Singh, R.; Gorovtsov, A.; Tsitsuashvili, V.; Purvis, O.; Ghazaryan, K.; et al. Effects of Zinc-oxide Nanoparticles on Soil, Plants, Animals and Soil Organisms: A Review. Environ. Nanotechnol. Monit. Manag. 2018, 9, 76-84. [CrossRef]

34. Kumar, R.; Sahoo, G.; Pandey, K.; Nayak, M.K.; Topno, R.; Rabidas, V.; Das, P. Virostatic potential of zinc oxide $(\mathrm{ZnO})$ nanoparticles on capsid protein of cytoplasmic side of chikungunya virus. Int. J. Infect. Dis. 2018, 73, 368. [CrossRef]

35. Dinh, C.T.; Nguyen, T.; Kleitz, F.; Do, T.-O. Shape-Controlled Synthesis of Highly Crystalline Titania Nanocrystals. ACS Nano. 2009, 3, 3737-3743. [CrossRef] [PubMed] 
36. Molnár, Z.; Bódai, V.; Szakacs, G.; Erdélyi, B.; Fogarassy, Z.; Sáfrán, G.; Varga, T.; Kónya, Z.; Tóth-Szeles, E.; Szúcs, R.; et al. Green synthesis of gold nanoparticles by thermophilic filamentous fungi. Sci. Rep. 2018, 8, 3943. [CrossRef] [PubMed]

37. Kharissova, O.V.; Kharisov, B.I.; Oliva González, C.M.; Méndez, Y.P.; López, I. Greener synthesis of chemical compounds and materials. R. Soc. Open Sci. 2019, 6, 191378. [CrossRef] [PubMed]

38. Singh, J.; Dutta, T.; Kim, K.-H.; Rawat, M.; Samddar, P.; Kumar, P. “Green” synthesis of metals and their oxide nanoparticles: Applications for environmental remediation. J. Nanobiotechnol. 2018, 16, 84. [CrossRef]

39. Krumpfer, J.; Schuster, T.; Klapper, M.; Müllen, K. Make it nano-Keep it nano. Nano Today 2013, 8, 417-438. [CrossRef]

40. Baun, A.; Sayre, P.; Steinhäuser, K.G.; Rose, J. Regulatory relevant and reliable methods and data for determining the environmental fate of manufactured nanomaterials. NanoImpact 2017, 8, 1-10. [CrossRef]

41. Mody, V.V.; Siwale, R.; Singh, A.; Mody, H.R. Introduction to metallic nanoparticles. J. Pharm. Bioallied Sci. 2010, 2, 282-289. [CrossRef]

42. Zhang, D.; Wei, L.; Zhong, M.; Xiao, L.; Li, H.-W.; Wang, J. The Morphology and Surface Charge-Dependent Cellular Uptake Efficiency of Upconversion Nanostructures Revealed by Single Particle Optical Microscopy. Chem. Sci. 2018, 9. [CrossRef]

43. Abdal Dayem, A.; Hossain, M.K.; Lee, S.B.; Kim, K.; Saha, S.K.; Yang, G.-M.; Choi, H.Y.; Cho, S.-G. The Role of Reactive Oxygen Species (ROS) in the Biological Activities of Metallic Nanoparticles. Int. J. Mol. Sci. 2017, 18, 120. [CrossRef]

44. Wang, D.; Zhao, L.; Ma, H.; Zhang, H.; Guo, L.-H. Quantitative Analysis of Reactive Oxygen Species Photogenerated on Metal Oxide Nanoparticles and Their Bacteria Toxicity: The Role of Superoxide Radicals. Environ. Sci. Technol. 2017, 51, 10137-10145. [CrossRef] [PubMed]

45. Moreno-Altamirano, M.M.B.; Kolstoe, S.E.; Sánchez-García, F.J. Virus Control of Cell Metabolism for Replication and Evasion of Host Immune Responses. Front. Cell. Infect. Microbiol. 2019, 9, 95. [CrossRef] [PubMed]

46. Mazzon, M.; Marsh, M. Targeting viral entry as a strategy for broad-spectrum antivirals. F1000Research 2019, 8. [CrossRef]

47. Lysenko, V.; Lozovski, V.; Lokshyn, M.; Gomeniuk, Y.; Dorovskih, A.; Rusinchuk, N.; Pankivska, Y.; Povnitsa, O.; Zagorodnya, S.; Tertykh, V.; et al. Nanoparticles as antiviral agents against adenoviruses. Adv. Nat. Sci. Nanosci. Nanotechnol. 2018, 9, 25021. [CrossRef]

48. Galdiero, S.; Falanga, A.; Vitiello, M.; Cantisani, M.; Marra, V.; Galdiero, M. Silver nanoparticles as potential antiviral agents. Molecules 2011, 16, 8894-8918. [CrossRef]

49. Mori, Y.; Ono, T.; Miyahira, Y.; Nguyen, V.; Matsui, T.; Ishihara, M. Antiviral activity of silver nanoparticle/chitosan composites against H1N1 influenza A virus. Nanoscale Res. Lett. 2013, 8, 93. [CrossRef]

50. Rezatofighi, S.E.; Rafiei, S.; Ardakani, M.; Madadgar, O. In vitro anti-foot-and-mouth disease virus activity of magnesium oxide nanoparticles. IET Nanobiotechnol. 2015, 9. [CrossRef]

51. Khandelwal, N.; Kaur, G.; Kumar, N.; Tiwari, A. Application of silver nanoparticles in viral inhibition: A new hope for antivirals. Dig. J. Nanomater. Biostruct. 2014, 9, 175-186.

52. Baram-Pinto, D.; Shukla, S.; Perkas, N.; Gedanken, A.; Sarid, R. Inhibition of Herpes Simplex Virus Type 1 Infection by Silver Nanoparticles Capped with Mercaptoethane Sulfonate. Bioconjug. Chem. 2009, 20, 1497-1502. [CrossRef]

53. Broglie, J.J.; Alston, B.; Yang, C.; Ma, L.; Adcock, A.F.; Chen, W.; Yang, L. Antiviral Activity of Gold/Copper Sulfide Core/Shell Nanoparticles against Human Norovirus Virus-Like Particles. PLoS ONE 2015, 10, e0141050. [CrossRef]

54. Zhong, J.; Xia, Y.; Hua, L.; Liu, X.; Xiao, M.; Xu, T.; Zhu, B.; Cao, H. Functionalized selenium nanoparticles enhance the anti-EV71 activity of oseltamivir in human astrocytoma cell model. Artif. Cells Nanomed. Biotechnol. 2019, 47, 3485-3491. [CrossRef] [PubMed]

55. Levina, A.S.; Repkova, M.N.; Bessudnova, E.V.; Filippova, E.I.; Mazurkova, N.A.; Zarytova, V.F. High antiviral effect of $\mathrm{TiO}_{2}$.PL-DNA nanocomposites targeted to conservative regions of (-)RNA and (+)RNA of influenza A virus in cell culture. Beilstein J. Nanotechnol. 2016, 7, 1166-1173. [CrossRef] [PubMed]

56. Cui, H.; Jiang, J.; Gu, W.; Sun, C.; Wu, D.; Yang, T.; Yang, G. Photocatalytic Inactivation Efficiency of Anatase Nano- $\mathrm{TiO}_{2}$ Sol on the $\mathrm{H}_{9} \mathrm{~N}_{2}$ Avian Influenza Virus. Photochem. Photobiol. 2010, 86, 1135-1139. [CrossRef] [PubMed] 
57. Mazurkova, N.A.; Spitsyna, Y.; Shikina, N.; Ismagilov, Z.; Zagrebelny, S.; Ryabchikova, E. Interaction of titanium dioxide nanoparticles with influenza virus. Nanotechnol. Russ. 2010, 5, 417-420. [CrossRef]

58. Liu, S.; Meng, X.-Y.; Perez-Aguilar, J.M.; Zhou, R. An In Silico study of $\mathrm{TiO}_{2}$ nanoparticles interaction with twenty standard amino acids in aqueous solution. Sci. Rep. 2016, 6, 37761. [CrossRef]

59. Mishra, Y.; Adelung, R.; Röhl, C.; Shukla, D.; Spors, F.; Tiwari, V. Virostatic potential of micro-nano filopodia-like ZnO structures against herpes simplex virus-1. Antivir. Res. 2011, 92, 305-312. [CrossRef]

60. Tavakoli, A.; Ataei-Pirkooh, A.; Mir Mohamad Sadeghi, G.; Bokharaei-Salim, F.; Sahrapour, P.; Kiani, S.; Moghoofei, M.; Farahmand, M.; Javanmard, D.; Monavari, S. Polyethylene glycol-coated zinc oxide nanoparticle: An efficient nanoweapon to fight against herpes simplex virus type 1. Nanomedicine 2018, 13. [CrossRef]

61. Cai, L.; Cai, L.; Jia, H.; Liu, C.; Wang, D.; Sun, X. Foliar Exposure of Fe3O4 Nanoparticles on Nicotiana benthamiana: Evidence for Nanoparticles Uptake, Plant Growth Promoter and Defense Response Elicitor against Plant Virus. J. Hazard. Mater. 2020, 393, 122415. [CrossRef]

62. El-Dougdoug, N.K.; Bondok, A.M.; El-Dougdoug, K.A. Evaluation of Silver Nanoparticles as Antiviral Agent Against ToMV and PVY in Tomato Plants. Middle East J. Appl. Sci. 2018, 08, 100-111.

63. Alkubaisi, N.A.; Aref, N.M.A. Dispersed gold nanoparticles potentially ruin gold barley yellow dwarf virus and eliminate virus infectivity hazards. Appl. Nanosci. 2017, 7, 31-40. [CrossRef]

64. Jain, D. Green Synthesis of Silver Nanoparticles and their Application in Plant Virus Inhibition. J. Mycol. Plant Pathol. 2014, 44, 21-24.

65. Elbeshehy, E.K.F.; Elazzazy, A.M.; Aggelis, G. Silver nanoparticles synthesis mediated by new isolates of Bacillus spp., nanoparticle characterization and their activity against Bean Yellow Mosaic Virus and human pathogens. Front. Microbiol. 2015, 6, 453. [CrossRef] [PubMed]

66. Wang, Y.; Sun, C.; Xu, C.; Wang, Z.; Zhao, M.; Wang, C.; Liu, L.; Chen, F. Preliminary experiments on nano-silver against tobacco mosaic virus and its mechanism. Tob. Sci. Technol. 2016, 49, 22-30. [CrossRef]

67. El-shazly, M.; Attia, Y.; Kabil, F.; Anis, E.; Hazman, M. Inhibitory Effects of Salicylic Acid and Silver Nanoparticles on Potato Virus Y-Infected Potato Plants in Egypt. Middle East J. Agric. Res. 2017, 6, 835-848.

68. Elazzazy, A.; Elbeshehy, E.; Betiha, M. In vitro assessment of activity of graphene silver composite sheets against multidrug-resistant bacteria and Tomato Bushy Stunt Virus. Trop. J. Pharm. Res. 2017, 16, 2705-2711. [CrossRef]

69. Shafie, R.M.; Salama, A.M.; Farroh, K.Y. Silver nanoparticles activity against Tomato spotted wilt virus. Middle East J. Agric. Res. 2018, 7, 1251-1267.

70. Aref, N.; Alkubaisi, N.; Marraiki, N.; Hindi, A. Multi-Functional Effects of Gold Nano-Particles Inducing Plant Virus Resistance Crops. In Proceedings of the 5th Annual World Congress of Industrial Biotechnology-2012, Xi'an, China, 25 April 2012.

71. Elsharkaway, M.; Derbalah, A. Antiviral activity of titanium dioxide nanostructures as a control strategy for broad bean strain virus in faba bean: Control of broad bean stain virus by $\mathrm{TiO}_{2}$ nanostructures. Pest Manag. Sci. 2018. [CrossRef]

72. Hao, Y.; Yuan, W.; Ma, C.; White, J.; Zhang, Z.; Adeel, M.; Zhou, T.; Yukui, R.; Xing, B. Engineered nanomaterials suppress Turnip mosaic virus infection in tobacco (Nicotiana benthamiana). Environ. Sci. Nano 2018, 5. [CrossRef]

73. El-Sawy, M.; Elsharkawy, M.; Abass, J.; Kasem, M. Antiviral Activity of 2-Nitromethyl Phenol, Zinc Nanoparticles and Seaweed Extract Against Cucumber mosaic virus (CMV) in Eggplant. J. Virol. Antivir. Res. 2017, 6. [CrossRef]

74. Elsharkawy, M.M.; Mousa, K.M. Induction of systemic resistance against Papaya ring spot virus (PRSV) and its vector Myzus persicae by Penicillium simplicissimum GP17-2 and silica $\left(\mathrm{SiO}_{2}\right)$ nanopowder. Int. J. Pest Manag. 2015, 61, 353-358. [CrossRef]

75. El-Sawy, M.; Elsharkawy, M.; Abass, J.; Hagag, E. Inhibition of Tomato Yellow Leaf Curl Virus by Zingiber offi cinale and Mentha longifolia Extracts and Silica Nanoparticles and Its Refl ection on Tomato Growth and Yield. Int. J. Antivir. Antiretrovir. 2017, 1, 1-6.

76. Derbalah, A.; Elsharkawy, M. A new strategy to control Cucumber mosaic virus using fabricated NiO-nanostructures. J. Biotechnol. 2019, 306. [CrossRef] [PubMed]

77. Eugene, K.; Zholobak, N. Antiviral Activity of Cerium Dioxide Nanoparticles on Tobacco Mosaic Virus Model. In Proceedings of the Topical Issues of New Drugs Development, Kharkiv, Ukraine, April 2016. 
78. Soares, C.; Pereira, R.; Fidalgo, F. Metal-Based Nanomaterials and Oxidative Stress in Plants: Current Aspects and Overview. In Phytotoxicity of Nanoparticles; Faisal, M., Saquib, Q., Alatar, A., Al-Khedhairy, A., Eds.; Springer International Publishing: Cham, Switzerland, 2018; pp. 197-227. ISBN 978-3-319-76707-9.

79. Tan, B.L.; Norhaizan, M.E.; Liew, W.-P.-P.; Sulaiman Rahman, H. Antioxidant and Oxidative Stress: A Mutual Interplay in Age-Related Diseases. Front. Pharmacol. 2018, 9, 1162. [CrossRef] [PubMed]

80. Rastogi, A.; Zivcak, M.; Sytar, O.; Kalaji, H.; Xiaolan, H.; Mbarki, S.; Brestic, M. Impact of Metal and Metal Oxide Nanoparticles on Plant: A Critical Review. Front. Chem. 2017, 5, 78. [CrossRef] [PubMed]

81. Landa, P.; Dytrych, P.; Prerostova, S.; Petrova, S.; Vankova, R.; Vanek, T. Transcriptomic Response of Arabidopsis thaliana Exposed to CuO Nanoparticles, Bulk Material, and Ionic Copper. Environ. Sci. Technol. 2017, 51, 10814-10824. [CrossRef] [PubMed]

82. Hernández-Hernández, H.; Juárez Maldonado, A.; Benavides-Mendoza, A.; Ortiz, H.; Cadenas-pliego, G.; Aspeytia, D.; González-Morales, S. Chitosan-PVA and Copper Nanoparticles Improve Growth and Overexpress the SOD and JA Genes in Tomato Plants under Salt Stress. Agronomy 2018, 8, 175. [CrossRef]

83. Vinković, T.; Novak, O.; Strnad, M.; Goessler, W.; Domazet Jurašin, D.; Parađiković, N.; Vinković Vrček, I. Cytokinin response in pepper plants (Capsicum annuum L.) exposed to silver nanoparticles. Environ. Res. 2017, 156, 10-18. [CrossRef]

84. Van Nhan, L.; Ma, C.; Rui, Y.; Liu, S.; Li, X.; Xing, B.; Liu, L. Phytotoxic Mechanism of Nanoparticles: Destruction of Chloroplasts and Vascular Bundles and Alteration of Nutrient Absorption. Sci. Rep. 2015, 5, 11618. [CrossRef]

85. Ali, S.; Ganai, B.A.; Kamili, A.N.; Bhat, A.A.; Mir, Z.A.; Bhat, J.A.; Tyagi, A.; Islam, S.T.; Mushtaq, M.; Yadav, P.; et al. Pathogenesis-related proteins and peptides as promising tools for engineering plants with multiple stress tolerance. Microbiol. Res. 2018, 212-213, 29-37. [CrossRef]

86. Marslin, G.; Sheeba, C.J.; Franklin, G. Nanoparticles Alter Secondary Metabolism in Plants via ROS Burst. Front. Plant Sci. 2017, 8, 832. [CrossRef]

87. Chung, I.-M.; Rekha, K.; Venkidasamy, B.; Thiruvengadam, M. Effect of Copper Oxide Nanoparticles on the Physiology, Bioactive Molecules, and Transcriptional Changes in Brassica rapa ssp. rapa Seedlings. Water Air Soil Pollut. 2019, 230, 48. [CrossRef]

88. Mazaheri Tirani, M.; Madadkar Haghjou, M.; Ismaili, A. Hydroponic grown tobacco plants respond to zinc oxide nanoparticles and bulk exposures by morphological, physiological and anatomical adjustments. Funct. Plant Biol. 2019, 46, 360-375. [CrossRef] [PubMed]

89. Juárez Maldonado, A.; Cadenas-pliego, G.; Pinedo-Espinoza, J.; López-Palestina, C.U.; Hernández-Fuentes, A.; Ortiz, H.; Valdés-Reyna, J. Foliar Application of $\mathrm{Cu}$ Nanoparticles Modified the Content of Bioactive Compounds in Moringa oleifera Lam. Agronomy 2018, 8, 167. [CrossRef]

90. Raigond, P.; Raigond, B.; Kaundal, B.; Singh, B.; Joshi, A.; Dutt, S. Effect of zinc nanoparticles on antioxidative system of potato plants. J. Environ. Biol. 2017, 38, 435-439. [CrossRef]

91. du Jardin, P. Plant biostimulants: Definition, concept, main categories and regulation. Sci. Hortic. 2015, 196, 3-14. [CrossRef]

92. Vazquez-Hernandez, C.; Feregrino-Perez, A.A.; Perez-Ramirez, I.; Ocampo-Velazquez, R.V.; Rico-García, E.; Torres-Pacheco, I.; Guevara-Gonzalez, R.G. Controlled elicitation increases steviol glycosides (SGs) content and gene expression-associated to biosynthesis of SGs in Stevia rebaudiana B. cv. Morita II. Ind. Crops Prod. 2019, 139, 111479. [CrossRef]

93. Worrall, E.; Hamid, A.; Mody, K.; Mitter, N.; Pappu, H. Nanotechnology for Plant Disease Management. Agronomy 2018, 8, 285. [CrossRef]

94. Panattoni, A.; Luvisi, A.; Triolo, E. Review. Elimination of viruses in plants: Twenty years of progress. Span. J. Agric. Res. 2013, 11, 173-188. [CrossRef]

95. Hoseinzadeh, E.; Makhdoumi, P.; Taha, P.; Stelling, J.; Hossini, H.; Kamal, M.; Ashraf, G. A Review on Nano-Antimicrobials: Metal Nanoparticles, Methods and Mechanisms. Curr. Drug Metab. 2016, 18. [CrossRef]

96. Siddiqi, K.; Husen, A. Plant Response to Engineered Metal Oxide Nanoparticles. Nanoscale Res. Lett. 2017, 12. [CrossRef]

97. Wang, D.; Ebbs, S.; Chen, Y.; Ma, X. Trans-generational impact of cerium oxide nanoparticles on tomato plants. Metallomics 2013, 5. [CrossRef] [PubMed] 
98. Hawthorne, J.; De la Torre Roche, R.; Xing, B.; Newman, L.A.; Ma, X.; Majumdar, S.; Gardea-Torresdey, J.; White, J.C. Particle-Size Dependent Accumulation and Trophic Transfer of Cerium Oxide through a Terrestrial Food Chain. Environ. Sci. Technol. 2014, 48, 13102-13109. [CrossRef] [PubMed]

99. You, T.; Liu, D.; Jing, C.; Yang, Z.; Dou, R.; Gao, X.; Wang, L. Effects of metal oxide nanoparticles on soil enzyme activities and bacterial communities in two different soil types. J. Soils Sediments 2017, 18. [CrossRef]

100. Priester, J.; Ge, Y.; Mielke, R.; Horst, A.; Moritz, S.; Espinosa, K.; Gelb, J.; Walker, S.; Nisbet, R.; An, Y.-J.; et al. Soybean susceptibility to manufactured nanomaterials with evidence for food quality and soil fertility interruption. Proc. Natl. Acad. Sci. USA 2012, 109, E2451-E2456. [CrossRef] [PubMed]

101. Shapiro, E.M. Biodegradable, polymer encapsulated, metal oxide particles for MRI-based cell tracking. Magn. Reson. Med. 2015, 73, 376-389. [CrossRef]

102. Keswani, C. Intellectual Property Issues in Nanotechnology; CRC Press: Cleveland, OH, USA, 2020; ISBN 978-0367482305.

103. Chen, J.; Shao, L. Mass production of nanoparticles by high gravity reactive precipitation technology with low cost. China Particuol. 2003, 1, 64-69. [CrossRef]

104. Lade, B.; Shanware, A. Phytonanofabrication: Methodology and Factors Affecting Biosynthesis of Nanoparticles. In Nanosystems; IntechOpen: Rijeka, Croatia, 2020.

105. Al-Dhabi, N.A.; Valan Arasu, M. Environmentally-Friendly Green Approach for the Production of Zinc Oxide Nanoparticles and Their Anti-Fungal, Ovicidal, and Larvicidal Properties. Nanomaterials 2018, 8, 500. [CrossRef]

106. Peralta-videa, J.; Huang, Y.; Parsons, J.; Zhao, L.; Lopez-Moreno, M.; Hernandez-Viezcas, J.; Gardea-Torresdey, J. Plant-based green synthesis of metallic nanoparticles: Scientific curiosity or a realistic alternative to chemical synthesis? Nanotechnol. Environ. Eng. 2016, 1, 4. [CrossRef]

107. Cobos, A.; Montes, N.; López-Herranz, M.; Gil-Valle, M.; Pagán, I. Within-Host Multiplication and Speed of Colonization as Infection Traits Associated with Plant Virus Vertical Transmission. J. Virol. 2019, 93, e01078-e01119. [CrossRef]

108. Sánchez-López, E.; Gomes, D.; Esteruelas, G.; Bonilla, L.; Lopez-Machado, A.L.; Galindo, R.; Cano, A.; Espina, M.; Ettcheto, M.; Camins, A.; et al. Metal-Based Nanoparticles as Antimicrobial Agents: An Overview. Nanomaterials 2020, 10, 292. [CrossRef]

(C) 2020 by the authors. Licensee MDPI, Basel, Switzerland. This article is an open access article distributed under the terms and conditions of the Creative Commons Attribution (CC BY) license (http://creativecommons.org/licenses/by/4.0/). 